\title{
Sporolactobacillus vineae sp. nov., a spore-forming lactic acid bacterium isolated from vineyard soil
}

\author{
Young-Hyo Chang, Min Young Jung, In-Soon Park and Hee-Mock Oh
}

Correspondence

Young-Hyo Chang

yhchang@kribb.re.kr
KCTC, Biological Resource Center, Korea Research Institute of Bioscience and Biotechnology, 52 Oeundong, Yuseong, Daejeon 305-806, Republic of Korea
Two spore-forming, facultatively anaerobic, lactic acid bacteria, strains SL153 ${ }^{\top}$ and SL1153, were isolated from vineyard soil in Korea. Cells of both strains were slightly curved, Gram-positive, motile rods that measured between 1 and $4 \mu \mathrm{m}$ in length and were approximately $0.5 \mu \mathrm{m}$ in diameter. Strains SL153 ${ }^{\top}$ and SL1153 fermented glucose, fructose, mannose and sorbitol, but were negative for nitrate reduction, catalase and oxidase. The predominant cellular fatty acids of the two isolates were iso- $\mathrm{C}_{15: 0}$, anteiso- $\mathrm{C}_{15: 0}$ and anteiso- $\mathrm{C}_{17: 0}$. meso-Diaminopimelic acid, glucose, mannose and galactose were determined in their whole-cell hydrolysates. 16S rRNA gene sequences from the two strains were almost identical $(99.9 \%)$ and they could be placed in the genus Sporolactobacillus according to phylogenetic analysis. The species most closely related to $\mathrm{SL} 153^{\top}$ were Sporolactobacillus inulinus and Sporolactobacillus terrae with $16 \mathrm{~S}$ rRNA gene similarities of 95.7 and $95.5 \%$, respectively, with the type strains. Levels of DNA-DNA relatedness between strain $S L 153^{\top}$ and the type strains of $S$. inulinus, $S$. terrae and Sporolactobacillus kofuensis were 18.5, 18.0 and 17.0\%, respectively. On the basis of the phylogenetic (16S rRNA gene), chemotaxonomic and phenotypic evidence given in this study, it is proposed that strains SL153 ${ }^{\top}$ and SL1153 should be assigned to the genus Sporolactobacillus as representatives of the novel species Sporolactobacillus vineae sp. nov. The type strain is $\mathrm{SL} 153^{\top}\left(=\mathrm{KCTC} 5376^{\top}=\mathrm{JCM} 14637^{\top}\right)$.
The genus Sporolactobacillus was defined by Kitahara \& Suzuki (1963) to accommodate a catalase-negative, sporeforming, homofermentative, lactic acid-producing bacterial species, Sporolactobacillus inulinus, within the family Lactobacillaceae. Later, the genus Sporolactobacillus was transferred to the family Bacillaceae by Kitahara \& Toyota (1972). More recently, in Bergey's Manual of Systematic Bacteriology, all members representing sporolactobacilli were grouped in the family 'Sporolactobacillaceae' (Garrity \& Holt, 2001). A comparison of physiological characteristics of species in the genus Sporolactobacillus and a sporeforming bacillus, Bacillus coagulans, revealed that members of the genus Sporolactobacillus lack catalase activity and require carbohydrate for growth (Yanagida et al., 1987).

Six species in the genus Sporolactobacillus have been reported; they are from rather limited isolation sources. S. inulinus was isolated from chicken feed (Kitahara \&

The GenBank/EMBL/DDBJ accession numbers for the $16 \mathrm{~S}$ rRNA gene sequences of strains SL153 ${ }^{\top}$ and SL1153 are EF581819 and EF581818, respectively.

A phylogenetic tree based on $16 \mathrm{~S}$ rRNA gene sequences using the neighbour-joining method showing the position of strains SL153 ${ }^{\top}$ and SL1153 and closely related strains of the family 'Sporolactobacillaceae' is available as supplementary material with the online version of this paper.
Suzuki, 1963) and the other species, Sporolactobacillus kofuensis, S. lactosus, S. laevolacticus, S. nakayamae and S. terrae, were isolated from the rhizosphere or soil around root hairs of a variety of wild plants collected in Japan and South-East Asia (Nakayama \& Yanoshi, 1967a, b; Yanagida et al., 1997). S. laevolacticus was reclassified from Bacillus laevolacticus Andersch et al. 1994 by Hatayama et al. (2006). Some evidence suggests that Sporolactobacillus species may be useful as a probiotic. Sporolactobacillus sp. L2407 presented antagonistic activity against Bacillus species (Holzapfel \& Botha, 1988) and S. inulinus BCRC 14647 inhibits the growth of Salmonella enteritidis BCRC 10744 (Huang et al., 2007).

In this study, the Sporolactobacillus-like strains, SL153 ${ }^{\mathrm{T}}$ and SL1153, which were isolated from a vineyard soil sample in Korea, are described. The micro-organisms were considered to be Sporolactobacillus on the basis of $16 \mathrm{~S}$ rRNA gene sequence comparisons. Accordingly, the aim of this present work was to elucidate the taxonomic position of strains SL153 ${ }^{\mathrm{T}}$ and SL1153 by means of phenotypic, genetic and chemotaxonomic analyses.

Strains SL153 ${ }^{\mathrm{T}}$ and SL1153 were isolated following the methods of Yanagida et al. (1997). One gram of soil sample was mixed with $9 \mathrm{ml} 0.75 \% \mathrm{NaCl}$ solution. The mixed solution was heated for $30 \mathrm{~min}$ at $60{ }^{\circ} \mathrm{C}$, after which one 
drop of the suspension broth was spread onto GYP agar [ $2 \%$ glucose, $1 \%$ yeast extract, $1 \%$ peptone, $1 \%$ sodium acetate and $0.5 \%(\mathrm{v} / \mathrm{v})$ salt solution, which comprised $4 \%$ $\mathrm{MgSO}_{4} .7 \mathrm{H}_{2} \mathrm{O}, 0.16 \% \mathrm{MnSO}_{4} \cdot 4 \mathrm{H}_{2} \mathrm{O}, 0.2 \% \mathrm{FeSO}_{4} \cdot 7 \mathrm{H}_{2} \mathrm{O}$ and $0.2 \% \mathrm{NaCl} ; \mathrm{pH} 6.8]$ plus $1 \% \mathrm{CaCO}_{3}$. The culture was incubated under anaerobic conditions at $30{ }^{\circ} \mathrm{C}$ for 2 3 days. After incubation, acid-producing bacteria were identified by the appearance of clear zones around colonies, selected and purified by repeated isolation.

Cells grown on GYP medium were used to determine the physiological characteristics of the isolates. Gram staining was performed using a Difco Gram stain set. Spore formation was determined by staining with malachite green. Morphology and cell size were examined using phase-contrast microscopy with a Nikon Optiphot-2 light microscope at 1500 magnification. For electron microscopy analysis, cells were negatively stained with $1 \%(\mathrm{w} / \mathrm{v})$ uranyl acetate according to the method described previously by Chang et al. (2002) and observed with a model H-7600 transmission electron microscope (Hitachi). Sugar fermentation patterns were determined using an API $50 \mathrm{CH}$ kit (bioMérieux). Catalase activity was determined by placing drops of $3 \%(\mathrm{v} / \mathrm{v}) \mathrm{H}_{2} \mathrm{O}_{2}$ on cultures growing on GYP and observing the production of oxygen bubbles. Oxidase activity was determined using an Oxy-swab (bioMérieux). For growth determination at various $\mathrm{pH}$ values ( $\mathrm{pH} 4.0-9.0$ in 1 unit increments), cells were inoculated in $\mathrm{pH}$-adjusted media at $30^{\circ} \mathrm{C}$ for $48 \mathrm{~h}$ and growth was measured by optical density at $595 \mathrm{~nm}$ (BioRad). To determine optimum growth temperature and tolerance to $\mathrm{NaCl}$, cells were cultured in GYP medium at temperatures of $15-60{ }^{\circ} \mathrm{C}$ and in $\mathrm{NaCl}$ concentrations of up to $7 \%(\mathrm{w} / \mathrm{v})$ for 2 days. Motility was observed in GYP medium with $0.4 \%$ agar. The production of lactic acid was confirmed using a D-lactic acid/L-lactic acid kit (Rbiopharm; Roche Diagnostics). Purified cell-wall preparations were obtained as described by Schleifer \& Kandler (1972). The amino acid and sugar analysis of whole-cell hydrolysates were performed as described by Staneck \& Roberts (1974) using TLC on cellulose plates with the solvent system of Rhuland et al. (1955).

Cells of the two isolates were motile, produced lactic acid, contained an oval spore and grew in GYP medium containing $7 \% \mathrm{NaCl}$. The strains were negative for nitrate reduction, catalase and oxidase, but positive for acid production from glucose and fructose. Single cells of strain SL153 ${ }^{\mathrm{T}}$ were observed as slightly curved rods that measured between 1 and $4 \mu \mathrm{m}$ in length and approximately $0.5 \mu \mathrm{m}$ in diameter. Electron micrographs of thin sections of cells showed that the cytoplasmic membrane of strain $\mathrm{SL} 153^{\mathrm{T}}$ was surrounded by a multilayered cell envelope composed of a relatively thin electron-dense (peptidoglycan) layer and at least two additional exterior layers (data not shown). Physiological properties and sugar fermentation patterns of strains SL153 ${ }^{\mathrm{T}}$ and SL1153 are shown in Table 1. These physiological properties are consistent with previous descriptions of members of the genus Sporolactobacillus (Nakayama \& Yanoshi, 1967a, b; Yanagida et al., 1997; Hatayama et al., 2006).

The 16S rRNA gene was amplified by PCR using universal primers 27F and 1492R, as described previously (Chang et al., 2001). Phylogenetic relationships between strains SL153 ${ }^{\mathrm{T}}$ and SL1153 and other Gram-positive, sporeforming bacilli were inferred from a comparison of $16 \mathrm{~S}$ rRNA gene sequences. Phylogenetic trees were inferred by using the neighbour-joining (Saitou \& Nei, 1987), FitchMargoliash (Fitch \& Margoliash, 1967) and maximumparsimony (Fitch, 1971) methods. Evolutionary distance matrices for the neighbour-joining and Fitch-Margoliash methods were generated according to the model of Jukes \& Cantor (1969). The PHYLIP package (Felsenstein, 1993) was used for all analyses. The resultant tree topology was evaluated by bootstrap analysis (Felsenstein, 1985) of the neighbour-joining tree based on 1000 resamplings.

A preliminary comparison of the nucleotide sequences with sequences in GenBank and the Ribosomal Database Project (Maidak et al., 2001) indicated that the isolates were closely related to members of the genus Sporolactobacillus. The $16 \mathrm{~S}$ rRNA gene sequences of the test strains were aligned manually with representatives of the genus Sporolactobacillus and related taxa. Phylogenetic trees showing the relationship between isolates and representatives of the family 'Sporolactobacillaceae' are given in Fig. 1 and Supplementary Fig. S1 (available in IJSEM Online). The test strains formed a highly significant monophyletic clade with members of the genus Sporolactobacillus, which currently contains six species with validly published names. The Sporolactobacillus clade was also confirmed in other treeing algorithms supported by a highly significant bootstrap value of $100 \%$. On the basis of pairwise $16 \mathrm{~S}$ rRNA gene sequence similarities, the closest relative to strain SL153 ${ }^{\mathrm{T}}$ was S. inulinus JCM $6014^{\mathrm{T}}(95.7 \%)$ followed by $S$. terrae JCM $3516^{\mathrm{T}}(95.5 \%)$ and S. kofuensis JCM $3419^{\mathrm{T}}(95.2 \%)$. The two sequences of SL153 ${ }^{\mathrm{T}}$ and SL1153 showed high similarity to each other $(99.9 \%)$ indicating that the two strains belong to the same species. It is evident from 16S rRNA gene sequence analysis that the two isolates represent a novel genomic species in the genus Sporolactobacillus, as none of the Sporolactobacillus species with validly published names showed more than $97 \% 16 \mathrm{~S}$ rRNA gene sequence similarity (Stackebrandt \& Goebel, 1994). Isolates SL153 ${ }^{\mathrm{T}}$ and SL1153 could also be clearly distinguished from the type species of the genus Sporolactobacillus.

The novel strains and some Sporolactobacillus reference strains were subjected to genomic relatedness analysis to confirm membership to the genus. DNA-DNA hybridization between strains SL153 ${ }^{\mathrm{T}}$ and SL1153 and their closest phylogenetic relatives based on 16S rRNA gene sequence similarity was determined by using the method described by Ezaki et al. (1989). Hybridization was carried out with photobiotin-labelled probes using a Fluoroskan Ascent Fluorescent plate reader (Thermo Life Science) with three 
Table 1. Differential physiological characteristics of strains $S L 153^{\top}$ and $S L 1153$ and related species

Strains: 1, SL153 ${ }^{\mathrm{T}}$ and SL1153 (S. vineae sp. nov.); 2, S. inulinus JCM $6014^{\mathrm{T}} ; 3$, S. terrae JCM $3516^{\mathrm{T}} ; 4$, S. nakayamae subsp. racemicus JCM $3417^{\mathrm{T}}$; 5 , S. kofuensis JCM $3419^{\mathrm{T}}$; 6, S. nakayamae subsp. nakayamae JCM $3514^{\mathrm{T}}$. +, Positive; -, negative; w, weakly positive. Cells of all strains are motile, produce lactic acid, have oval shaped spores and grow in $5 \% \mathrm{NaCl}$. All strains are negative for catalase and oxidase, but positive for acid production from glucose, fructose, mannose and $\mathrm{N}$-acetylglucosamine. For determination of acid production, cultures were incubated in GYP medium at $30{ }^{\circ} \mathrm{C}$ for $48 \mathrm{~h}$.

\begin{tabular}{|c|c|c|c|c|c|c|}
\hline Characteristic & 1 & 2 & 3 & 4 & 5 & 6 \\
\hline Growth temperature range $\left({ }^{\circ} \mathrm{C}\right)$ & $25-40$ & $25-40$ & $25-45$ & $15-40$ & $25-40$ & $25-40$ \\
\hline Optimal temperature $\left({ }^{\circ} \mathrm{C}\right)$ & 37 & 37 & 30 & 30 & 37 & 37 \\
\hline Growth in $7 \% \mathrm{NaCl}$ & + & $\mathrm{w}$ & + & + & $\mathrm{w}$ & $\mathrm{w}$ \\
\hline $\mathrm{pH}$ range for growth & $6.0-7.0$ & $6.0-7.0$ & $6.0-8.0$ & $5.0-8.0$ & $6.0-7.0$ & $6.0-8.0$ \\
\hline \multicolumn{7}{|l|}{ Acid production from: } \\
\hline Galactose & - & - & - & + & - & - \\
\hline Sorbose & + & - & + & + & - & + \\
\hline Mannitol & + & + & + & - & + & - \\
\hline Sorbitol & + & + & - & - & - & - \\
\hline Methyl $\alpha$-D-glucoside & + & + & - & - & - & - \\
\hline Amygdalin & - & - & - & $\mathrm{w}$ & - & - \\
\hline Aesculin & - & - & - & + & - & - \\
\hline Salicin & - & - & - & + & - & - \\
\hline Cellobiose & - & - & - & + & - & - \\
\hline Maltose & $\mathrm{W}$ & $\mathrm{W}$ & - & + & + & + \\
\hline Melibiose & - & - & - & + & - & - \\
\hline Sucrose & $\mathrm{w}$ & + & + & + & + & + \\
\hline Trehalose & $\mathrm{W}$ & + & + & - & + & - \\
\hline Inulin & - & + & - & - & - & - \\
\hline Raffinose & - & + & - & + & - & + \\
\hline Starch & - & - & - & - & + & - \\
\hline Gentiobiose & - & - & - & + & - & - \\
\hline Turanose & + & + & - & - & - & - \\
\hline D-Tagatose & - & + & + & + & + & + \\
\hline
\end{tabular}

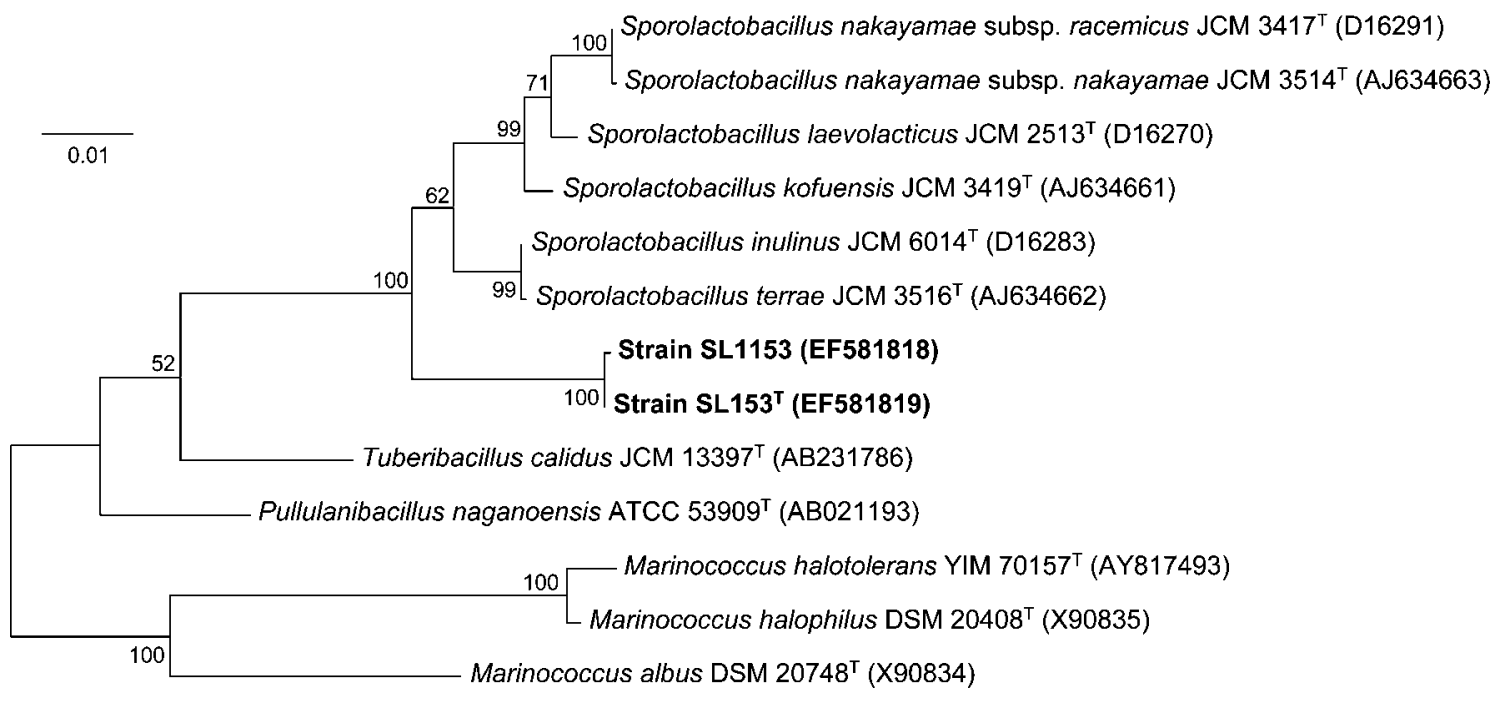

Fig. 1. Phylogenetic tree based on $16 \mathrm{~S}$ rRNA gene sequences using the maximum-parsimony method showing the phylogenetic position of strain $S L 153^{\top}$ and closely related strains of the family 'Sporolactobacillaceae'. Bootstrap values (1000 replications) of $50 \%$ or greater are shown at the nodes. Bar, 0.01 substitutions per nucleotide position. 
replications for each sample at $45{ }^{\circ} \mathrm{C}$. The genomic relatedness value between the two isolates was $81.9 \%$. This value indicates that strains $\mathrm{SL}_{153}{ }^{\mathrm{T}}$ and SL1153 represent the same species of Sporolactobacillus. The type strains of other Sporolactobacillus species were more distantly related to strain $\mathrm{SL} 153^{\mathrm{T}}$. The genomic relatedness values of the type strains of $S$. inulinus, $S$. terrae and $S$. kofuensis were $18.5,18.0$ and $17.0 \%$, respectively. These values are below the $70 \%$ threshold suggested for species delineation (Stackebrandt \& Goebel, 1994). These low values indicate that strain $\mathrm{SL}_{153}{ }^{\mathrm{T}}$ represents a novel species.

Cellular fatty acid compositions were determined for strains SL153 ${ }^{\mathrm{T}}$ and SL1153 grown on GYP agar for 2 days. Saponification, methylation and extraction were performed according to the standard protocol of the Sherlock Microbial Identification System (MIDI). The fatty acids were analysed by GC (model 6890N and autosampler 7683; Agilent) and identified using the Microbial Identification Sherlock software package.

The major cellular fatty acids of all Sporolactobacillus

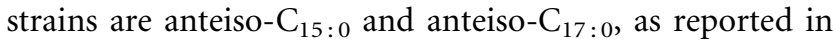
previous studies (Yanagida et al., 1997). However, the predominant cellular fatty acids of the two isolates were iso- $\mathrm{C}_{15: 0}$, anteiso- $\mathrm{C}_{15: 0}$ and anteiso- $\mathrm{C}_{17: 0}$ (Table 2). Moreover, significant differences were found in the relative amounts of iso- $\mathrm{C}_{15: 0}$ and anteiso- $\mathrm{C}_{15: 0}$ fatty acids, which can be used to differentiate these isolates from other members of the genus.

In the whole-cell hydrolysate analysis, meso-diaminopimelic acid, glucose, mannose and galactose were determined in the isolates. The predominant amino acid and sugars determined in the cell wall components of the isolates correlated with those of the type strain of S. inulinus.

DNA was prepared according to Chang et al. (2002) and the DNA G $+\mathrm{C}$ value (mol\%) was determined using the thermal denaturation method (Mandel \& Marmur, 1968). The relative $\mathrm{G}+\mathrm{C}$ contents were calculated by using standard DNA of Escherichia coli. The DNA G + C contents of strain $\mathrm{SL}_{153}{ }^{\mathrm{T}}$ and SL1153 were 50.6 and $51.6 \mathrm{~mol} \%$, respectively. These values were a little higher than those reported for S. inulinus (47.0-50.2 mol\%), S. terrae (43$46 \mathrm{~mol} \%$ ) and S. kofuensis (43 mol\%; Yanagida et al., 1987, 1997), but the taxonomic position of the isolates still lies in the same genus, as determined by $16 \mathrm{~S}$ rRNA gene sequence analysis. On the basis of molecular, chemical and phenotypic evidence presented in this study, it is proposed that strain SL153 ${ }^{\mathrm{T}}$, isolated from vineyard soil, should be classified in the genus Sporolactobacillus as a representative of the novel species Sporolactobacillus vineae sp. nov.

\section{Description of Sporolactobacillus vineae sp. nov.}

Sporolactobacillus vineae (vin'e.ae. L. gen. n. vineae of a vineyard).

Cells are Gram-positive, catalase- and oxidase-negative, motile by peritrichous flagella, produce DL-lactic acid and have oval shaped spores. Nitrate reduction is negative. Colonies on GYP agar are round, smooth, ivory-white and approximately $1.5-3.0 \mathrm{~mm}$ in diameter. Single cells are slightly curved rods that measure between 1 and $4 \mu \mathrm{m}$ in length and are approximately $0.5 \mu \mathrm{m}$ in diameter. Growth occurs at temperatures between 25 and $40{ }^{\circ} \mathrm{C}$ in GYP medium (optimum $37^{\circ} \mathrm{C}$ ). Grows in the presence of up to $7 \% \mathrm{NaCl}$ and the optimal $\mathrm{pH}$ range for growth is 6.0-7.0. Facultatively anaerobic. Grows well on GYP agar when incubated under anaerobic conditions. Acid is produced from glucose, fructose, mannose, sorbose, mannitol, sorbitol, methyl $\alpha$-D-glucoside, $N$-acetylglucosamine and turanose. Galactose, amygdalin, aesculin, salicin, cellobiose, melibiose, inulin, raffinose, starch, gentiobiose and Dtagatose are not fermented. Maltose, sucrose and trehalose are weakly fermented. The diagnostic amino acid is mesodiaminopimelic acid and the major cell wall sugars are glucose, mannose and galactose. Cells cultured in GYP medium contain iso- $\mathrm{C}_{15: 0}$, anteiso- $\mathrm{C}_{15: 0}$ and anteiso- $\mathrm{C}_{17: 0}$ as predominant cellular fatty acids. DNA $\mathrm{G}+\mathrm{C}$ content is $50.6-51.6 \mathrm{~mol} \%$.

The type strain is $\mathrm{SL} 153^{\mathrm{T}}\left(=\mathrm{KCTC} 5376^{\mathrm{T}}=\mathrm{JCM} 14637^{\mathrm{T}}\right)$, isolated from vineyard soil. Strain SL1153, also isolated from vineyard soil, is a reference strain.

Table 2. Cellular fatty acid composition (\%) of strains SL153 ${ }^{\top}$ and SL1153 and related species

Strains: 1, SL153 ${ }^{\mathrm{T}}$; 2, SL1153; 3, S. inulinus JCM 6014 ${ }^{\mathrm{T}} ; 4$, S. terrae JCM $3516^{\mathrm{T}} ; 5$, S. nakayamae subsp. racemicus JCM $3417^{\mathrm{T}}$; 6, S. kofuensis JCM $3419^{\mathrm{T}} ; 7$, S. nakayamae subsp. nakayamae JCM $3514^{\mathrm{T}}$. tr, Trace amount $(<1.0 \%)$; - , not detected.

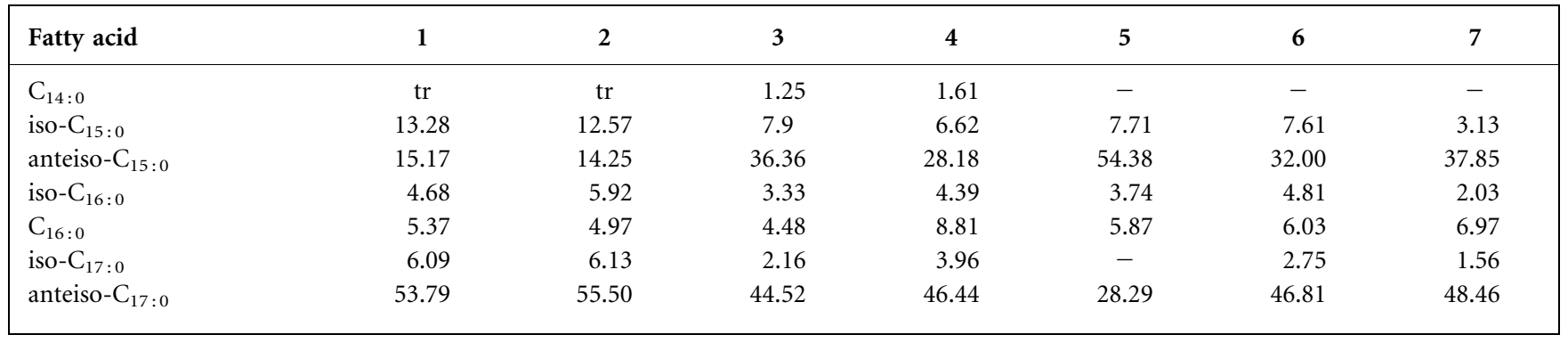




\section{Acknowledgements}

We are grateful to Dr Jean P. Euzéby (Society for Systematic and Veterinary Bacteriology, France) for his advice on nomenclatural queries. This work was supported by the KRIBB Research Initiative Program, Republic of Korea.

\section{References}

Chang, Y.-H., Kim, J.-K., Kim, H.-J., Kim, W.-Y., Kim, Y.-B. \& Park, Y.-H. (2001). Selection of a potential probiotic Lactobacillus strain and subsequent in vivo studies. Antonie van Leeuwenhoek 80, 193-199.

Chang, Y.-H., Han, J.-I., Chun, J., Lee, K. C., Rhee, M.-S., Kim, Y.-B. \& Bae, K. S. (2002). Comamonas koreensis sp. nov., a non-motile species from wetland in Woopo, Korea. Int J Syst Evol Microbiol 52, 377-381.

Ezaki, T., Hashimoto, Y. \& Yabuuchi, E. (1989). Fluorometric deoxyribonucleic acid-deoxyribonucleic acid hybridization in microdilution wells as an alternative to membrane filter hybridization in which radioisotopes are used to determine genetic relatedness among bacterial strains. Int J Syst Bacteriol 39, 224-229.

Felsenstein, J. (1985). Confidence limits on phylogenies: an approach using the bootstrap. Evolution 39, 783-791.

Felsenstein, J. (1993). PHYLIP (phylogeny inference package) version 3.5c. Distributed by the author. Department of Genome Sciences, University of Washington, Seattle, USA.

Fitch, W. M. (1971). Toward defining the course of evolution: minimum change for a specific tree topology. Syst Zool 20, 406-416.

Fitch, W. M. \& Margoliash, E. (1967). Construction of phylogenetic trees. Science 155, 279-284.

Garrity, G. M. \& Holt, J. G. (2001). The road map to the Manual. In Bergey's Manual of Systematic Bacteriology, 2nd edn, vol. 1, pp. 119166. Edited by D. R. Boone, R. W. Castenholz \& G. M. Garrity. New York: Springer

Hatayama, K., Shoun, H., Ueda, Y. \& Nakamura, A. (2006). Tuberibacillus calidus gen. nov., sp. nov., isolated from a compost pile and reclassification of Bacillus naganoensis Tomimura et al. 1990 as Pullulanibacillus naganoensis gen. nov., comb. nov. and Bacillus laevolacticus Andersch et al. 1994 as Sporolactobacillus laevolacticus comb. nov. Int J Syst Evol Microbiol 56, 2545-2551.

Holzapfel, W. H. \& Botha, S. J. (1988). Physiology of Sporolactobacillus strains isolated from different habitats and the indication of in vitro antagonism against Bacillus species. Int J Food Microbiol 7, 161-168.

Huang, H.-Y., Huang, S.-Y., Chen, P.-Y., King, V.-A., Lin, Y.-P. \& Tsen, J.-H. (2007). Basic characteristics of Sporolactobacillus inulinus BCRC 14647 for potential probiotic properties. Curr Microbiol 54, 396-404.
Jukes, T. H. \& Cantor, C. R. (1969). Evolution of protein molecules. In Mammalian Protein Metabolism, vol. 3, pp. 21-132. Edited by H. N. Munro. New York: Academic Press.

Kitahara, K. \& Suzuki, J. (1963). Sporolactobacillus nov. subgen. J Gen Appl Microbiol 9, 59-71.

Kitahara, K. \& Toyota, T. (1972). Auto-spheroplastization and cellpermeation in Sporolactobacillus inulinus. J Gen Appl Microbiol 18, 99-107.

Maidak, B. L., Cole, J. R., Lilburn, T. G., Parker, C. T., Jr, Saxman, P. R., Farris, R. J., Garrity, G. M., Olsen, G. J., Schmidt, T. M. \& Tiedje, J. M. (2001). The RDP-II (Ribosomal Database Project). Nucleic Acids Res 29, 173-174.

Mandel, M. \& Marmur, J. (1968). Use of ultraviolet absorbancetemperature profile for determining the guanine plus cytosine content of DNA. Methods Enzymol 12B, 195-206.

Nakayama, O. \& Yanoshi, M. (1967a). Spore-bearing lactic acid bacteria isolated from rhizosphere. II. Taxonomic studies on the catalase-negative strains. J Gen Appl Microbiol 13, 155-165.

Nakayama, O. \& Yanoshi, M. (1967b). Spore-bearing lactic acid bacteria isolated from rhizosphere. I. Taxonomic studies on Bacillus laevolacticus nov. sp. and Bacillus racemilacticus nov. sp. J Gen Appl Microbiol 13, 139-153.

Rhuland, L. E., Work, E., Denman, R. F. \& Hoare, D. S. (1955). The behavior of the isomers of $\alpha, \varepsilon$-diaminopimelic acid on paper chromatograms. J Am Chem Soc 77, 4844-4846.

Saitou, N. \& Nei, M. (1987). The neighbor-joining method: a new method for reconstructing phylogenetic trees. Mol Biol Evol 4, 406-425.

Schleifer, K. H. \& Kandler, O. (1972). Peptidoglycan types of bacterial cell walls and their taxonomic implications. Bacteriol Rev 36, 407-477.

Stackebrandt, E. \& Goebel, B. M. (1994). Taxonomic note: a place for DNA-DNA reassociation and $16 \mathrm{~S}$ rRNA sequence analysis in the present species definition in bacteriology. Int J Syst Bacteriol 44, 846849.

Staneck, J. L. \& Roberts, G. D. (1974). Simplified approach to identification of aerobic actinomycetes by thin-layer chromatography. Appl Microbiol 28, 226-231.

Yanagida, F., Suzuki, K.-I., Kaneko, T., Kozaki, M. \& Komagata, K. (1987). Morphological, biochemical, and physiological characteristics of spore-forming lactic acid bacteria. J Gen Appl Microbiol 33, 33-45.

Yanagida, F., Suzuki, K.-I., Kozaki, M. \& Komagata, K. (1997). Proposal of Sporolactobacillus nakayamae subsp. nakayamae sp. nov., subsp. nov., Sporolactobacillus nakayamae subsp. racemicus subsp. nov., Sporolactobacillus terrae sp. nov., Sporolactobacillus kofuensis sp. nov., and Sporolactobacillus lactosus sp. nov. Int J Syst Bacteriol 47, 499-504. 